Journal of Education and Educational Development

$8(1), 27-52,2021$

DOI: http://dx.doi.org/10.22555/joeed.v8i1.96

\title{
Investigation of the Relationship between Pre-service Teachers' Learning Styles and Their Critical Thinking Disposition
}

\author{
Mustafa Yeler \\ Mehmet Akif Ersoy University, Turkey \\ Gürbüz Ocak \\ Afyon Kocatepe University, Turkey
}

\begin{abstract}
This study investigates the relationship between pre-service teachers' learning styles (LS) and their critical thinking disposition (CTD). The study was carried out with the participation of 358 candidate teachers- 243 female and 115 maleswho study in different programs in the Faculty of Education at Burdur Mehmet Akif Ersoy University, Turkey. Grasha-Reichmann Learning Style Scales (1974) and Critical Thinking Disposition Scales by Semerci (2016) were used as data collecting tools. The obtained data were analyzed using parametric tests t-test, ANOVA, Pearson correlation, two-way ANOVA, and regression. In all analyses, $p<.05$ significance level was identified. It was found that there was a significant relationship at a moderate level between the $L S$ and the critical thinking tendencies of the candidate teachers. Depending on the variables such as age, gender, the type of high school, and departments, a moderate relationship was found between LS and critical thinking tendencies. While the common impact of age and LS; gender and LS; the high school type and LS were not significant, the common impact of department and LS were found to be significant at a moderate level. On the other hand, when the departments, high school types, and LS are considered together, it is found that each binary variable can explain approximately $25 \%$ of critical thinking dispositions. In the light shed by these results, it is suggested that the LS and critical thinking tendencies must be considered together in teaching-learning processes designed for candidate teachers.
\end{abstract}

Keywords: critical thinking, critical thinking disposition, learning style, teachinglearning processes. 


\section{Introduction}

One of the most important characteristics of a human being, defined as a bio-psycho-social being, is the ability to learn and think. Learning is generally defined as the process of creating or acquiring knowledge that creates changes in an individual's behavior; actively and consciously obtaining new information and associating it with existing information (Ar1, 2011). When theories about what learning is and how it occurs are examined, it is seen that for behaviorists, learning is a change in the behavior due to experiences. Cognitive experts define learning as a change that occurs in the information stored in memory through mental processes (Schunk, 2009); and according to the constructivist approach, it is the change that occurs in the meaning as a result of experiences (Perkins, 1999). In addition, Pritchard (2015) describes learning as behavioral change that occurs due to experience, the knowledge acquisition process in which behavior is shaped or controlled and an individual process in which understanding is structured based on gaining experience from various sources.

In these definitions of learning, the concepts of acquisition, individual experience, achievement, construct, etc. emphasize the 'individuality' of learning. The fact that learning is an individual process necessitates actions and interactions specific to individuals in this context. Besides, scientific, social, and technological developments in today's world have indicated the importance that each individual is different and that everyone learns differently. Therefore, it is important to recognize individual characteristics for the teaching-learning process to be more effective. These requirements have led to the emergence of the concepts such as LS, learning preferences, learning strategies, learning approaches, etc., which have been used intensely in educational sciences today and emphasize individual characteristics.

Learning style (LS) is defined and classified in many different ways in the literature. Snyder (2000) defines learning style as individual differences in the knowledge acquisition process. Felder and Silverman (1988) define learning style as typical strengths and preferences of individuals in the process of receiving, storing, and processing information. Within this framework, LS is considered as an 'individual learning path' (Bilasa, 2013), a personal characteristic of how the student will use information processing processes (Claxton \& Ralston, 1990; 1978; Litzinger, et al., 2007; Patureau, 1990), the basic elements and preferences for learning (Dunn \& Dunn, 1986; Mumford, 1987), and dispositions and processes 
observed in student behaviors (Entwistle, 1981; Kolb, 1984). On the other hand, Gencel (2016) emphasizes that LS is genetic and is determined at birth.

There are various classifications for the LS. Among these classifications, include experienced-based learning; Gregorc focuses on personal awareness, perception in learning, and cognitive processes in learning; whereas, Dunn and Dunn (1986) take the affective and physiological processes into account. According to Grasha (1996), learning style is related to how the individual interacts with the stimulant in the learning process. Learning style is the characteristics that affect a person's participation in learning experiences, getting information, interacting with peers and teachers (Grasha, 1996). Grasha and Reichmann differ from other classifications more advantageously because they assume that determining students' LS by considering the real behaviors in learning environments is likely to yield more valid and reliable results. They, therefore, allow teachers to determine appropriate teaching techniques based on these styles.

In conclusion, learning style is a characteristic that individuals are born with, that enables them to recognize themselves and have cognitive, affective, and environmental aspects that do not change or change very little during the life of a person (Kürüm, 2008). For this reason, revealing or knowing which learning style is considered as one of the most basic elements that will make a person successful in life, be it, education, work, or social life (Biggs, 2001). Because of these important functions in an individual's life, LS features that should be analyzed and evaluated very well by both students and teachers in the education process; because in the teaching-learning process, knowing the dimensions of how the individual perceives learning, what his/her expectations are and how he/she learns, learning speed, have significant value in terms of arranging the principles, variables, methods, techniques in this process and in terms of taking measures for the learning difficulties and barriers to be encountered (Domino, 1970; Felder, 1996; Özer, 2002; Senemoğlu, 2018; Tatar \& Tatar, 2007).

In this process, it can be ensured that individuals have rich learning experiences with group activities that will be organized in line with their differences and common characteristics by determining their LS (Given, 1996 as cited in Veznedaroğlu \& Özgür, 2005). 
Thinking is a feature that makes human beings different from other living things, is regarded as a purposeful mental operation used to overcome the conditions that disturb the individual (Kazanc1, 1989); whereas, Çubukçu (2011) defines this process as a skill that can be taught to process information. Thinking, in this context, is an effort to produce unknown by using the known; and is a series of mental actions that start with questioning and end with the production of new ideas (Başar, 2013).

As can be understood from these definitions, thinking is an inevitable process that includes purposeful and organized cognitive processes that a person has to use to survive. The main purpose of this process is to make sense of the events around us, classify them and make them unique (Paul \& Elder, 2013). There are various ways of thinking in this process. These thinking styles also appear with different classifications in the literature. For example, Cohen (1991 as cited in Alkın-Şahin \& Tunca, 2013) classified thinking skills into four groups: Problemsolving, decision making, creative thinking, and critical thinking. Çubukçu (2011) added logical reasoning to these groups and assessed critical thinking skills under seven titles as critical thinking, problem-solving, reading comprehension, writing, scientific thinking, creative thinking, and creative problem-solving.

As can be seen in the groupings of basic thinking styles in the literature, critical thinking is one of these skills. Ennis (1986) defines critical thinking as comparable reflective thinking that focuses on deciding what the individual believes or does. On the other hand, Paul and Elder (2013) define critical thinking skill as the art of analyzing and evaluating to improve thinking. Özden (2005) emphasizes that critical thinking encompasses skills such as evaluating prejudices, consistency, and inferences; distinguishing assumptions, ideas and claims; realizing the missing parts of the justifications and ambiguities in the explanations; assessing the adequacy of definitions and the appropriateness of results. Facione (1998 as cited in Özdemir, 2005) stated that in the critical thinking process, judgment and decisionmaking processes take place in addition to interpretation, analysis, evaluation, and inferences. This power is reflective, active, purposeful, dependent on standards, requires attention, and is productive (Fisher, 2001; Norris, 1985; Nosich, 2012). It can be said that critical thinking with these features is also a disciplined and selfcontrolled way of thinking to reveal perfect and complete thinking (Sönmez, 2012). 
Today, globalization and information society processes have necessitated educating people in the best and most effective way within the framework of their differences. To solve problems they encounter, the individuals of the information society should make good and informed decisions, to reveal different perspectives and preferences, to question the reliable and purposeful information among the masses to act and think quickly and effectively (Bulurman, 2006; Drucker, 1993; Yurdakul, 2004). Therefore, critical thinking processes are required to determine the quality and the validity of the knowledge that we have. From these points of view, raising individuals who have learned to learn and to think should be the common goal of all education systems (Meyers, 1986). In this context, it is among the primary goals of education systems to make individuals acquire the skills of searching for the solution to the problem he/she encounters, questioning, criticizing according to the conditions, and thinking creatively (Doğan, 2004; Helvac1, 1998). The most basic way to achieve this goal is to raise people who have thinking skills and can use them effectively in their lives. Based on this, the primary task of education is to raise people by taking into account individual differences, especially LS.

The concepts of Learning Style (LS) and Critical Thinking Disposition (CTD) appear as two important issues that have been studied extensively in the literature, either separately or from different perspectives. Studies investigating the relationship between LS and critical thinking skills have shown that there is a relationship between them according to the different variables, theoretical dimension, and data collection tools. In some of these studies (Colucciello, 1999; Dilekli, 2017; Ghazivakili et al., 2018; Siriopoulos \& Pomonis, 2007), a significant relationship was obtained between LS and components of CTD. On the contrary, in some studies, it was obtained that there was not a significant relationship between LS and critical thinking skills (Beşoluk \& Önder, 2010; Conceição, 2004; Gadzella et al., 1999; Kiriş-Avaroğulları \& Şaman, 2020; Kösece et al., 2015; Mahmoud, 2012; Mcdade, 2000; Mohomad et al., 2017; Myers \& Dyer, 2006).

On the other hand, according to Güven and Kürüm (2006), studies that mention the existence of a relationship between these two concepts in the literature do not contain a detailed finding and explanation regarding the content, direction, and amount of this relationship. Despite these reasons and their importance as revealed above in various dimensions, it is thought that few studies are trying to explain the relationship between LS and CTD, but the obtained findings are 
limited. This research is considered important as it is expected to both eliminate these deficiencies in the literature and reveal the direction and quantity of a possible relationship between these two concepts. Based on this, the following problems are tried to be answered.

\section{Research Question}

Is there a significant relationship between the LS of pre-service teachers and their CTD in terms of various variables?

\section{Sub Research Questions}

1. Is there a significant relationship between pre-service teachers' LS and CTD?

2. Is there a significant relationship between pre-service teachers' LS and CTD in terms of
a) age
b) gender,
c) type of graduated high school
d) department variables?

3. Is there a significant difference between the CTD of pre-service teachers and

a) their age and LS?

b) their gender and their LS?

c) the graduated high school type and their LS?

d) their departments and their LS?

4. Are the pre-service teachers' LS differentiated according to
a) age
b) gender
c) graduated high school type
d) department of pre-service teachers as a significant predictor of their CTD? 


\section{Methodology}

\section{Research Design}

This study aims to determine the relationship between LS and CTD in terms of various variables. Within the framework of this purpose, it will also be revealed whether LS predicts CTD. In this respect, a correlation research model was employed. The correlational research model aims to determine the relationships between two or more variables, the existence or degree of change together without interfering with the variables. The findings obtained with this model may give an idea to the researcher that a cause-effect relationship may occur between variables, but it cannot be interpreted as cause-effect (Büyüköztürk et al. 2011; Creswell, 2013; Gürbüz \& Şahin, 2017; Mertens, 1998).

\section{Sample}

The study universe consisted of 612 pre-service teachers (387 female, 225 male) who are freshmen at Burdur Mehmet Akif Ersoy University Faculty of Education. A total of 237 pre-service teachers were identified by proportioned sampling from the departments of English Language Teaching, Social Studies, Turkish, Preschool, Mathematics, Primary Education, Guidance, and Psychological Counseling randomly. The confidence interval value was taken as .05 taking into account the table values in Yazıcıoglu ve Erdoğan (2004) (p.49-50). For this sampling, the universe is divided into sub-universes that are homologous to one another regarding a certain variable that is considered important in terms of research. Then, from each of these sub-universes, element sampling is performed. The number of elements to be taken from each sub-universe is determined by the proportion of that sub-universe in the whole universe. Thus, it is ensured that the sample to be taken is represented by all sub-sections of the universe (Karasar, 2011, p. 113). Accordingly, a total of 358 participants, 243 female, and 115 male, were identified as participants. The participants in the sample group accounted for $58 \%$ of the study population.

\section{Instrument}

Grasha-Reichmann's Learning Style Scale (GRLSS) and Critical Thinking Disposition Scale (CTDS) developed by Semerci (2016) were used.

Grasha-Reichmann's Learning Style Scale (GRLSS-1974) developed by 
Grasha-Reichmann in 1974 and adapted to Turkish by Sarıtaş and Süral (2010) was employed to determine the LS of pre-service teachers. The scale consists of six sub-dimensions: autonomous, avoidant, collaborative, dependent, competitive, and participant LS. Sarıtaş and Süral conducted their study on 2nd-year and 3rd-year teacher candidates. In the scale adaptation process, the English form was applied to 60 students studying at English Teaching Department. 10 days later, the Turkish version of the scale was applied to 440 students. The correlation between the two applications was examined. The significance level was calculated as .62 by applying the Pearson Correlation test between these two applications. The Cronbach Alpha coefficient for the pilot application of the scale was .767; .802 was calculated for the actual application (Sarıtaş \& Süral, 2010)

In this study, the Cronbach alpha coefficient of the scale was 792. In addition, this value was obtained as $\alpha=.554 ; .682 ; .717 ; 547 ; .780 ; .646$ for the sub-dimensions, respectively. While determining LS, Grasha-Reichmann identified each learning style at three levels: "low", "medium" and "high". These levels are given in Table 1.

\section{Table 1}

Scores of LS in GRLSS

\begin{tabular}{lccc}
\hline \multirow{2}{*}{ SS } & \multicolumn{3}{c}{ Degree of LS } \\
\cline { 2 - 4 } & Low & Medium & High \\
\hline Autonomous & $1.0-2.7$ & $2.8-3.8$ & $3.9-5.0$ \\
Avoidant & $1.0-1.8$ & $1.9-3.1$ & $3.2-5.0$ \\
Collaborative & $1.0-2.7$ & $2.8-3.4$ & $3.5-5.0$ \\
Dependent & $1.0-2.9$ & $3.0-4.0$ & $4.1-5.0$ \\
Competitive & $1.0-1.7$ & $1.8-2.8$ & $2.9-5.0$ \\
Participant & $1.0-3.0$ & $3.1-4.1$ & $4.2-5.0$ \\
\hline
\end{tabular}

The items in the scale were graded as "strongly disagree", "disagree", "slightly agree", "agree" and "strongly agree".

Critical Thinking Disposition Scale (CTDS) developed by Semerci (2016) was also used in this study. This scale, which was implemented through the testretest method with the participation of 1081 university students and teachers. Factor loads were seen to vary between $0.33-0.71$ and item-total correlations ranged from 
$0.30-0.70$. The test-retest correlation of the scale was 0.76 and the correlation coefficient between the two-half scores was 0.95. The Cronbach Alpha coefficient of the CTD scale was 0.96 . On the other hand, the fit index values $(\chi 2 / \mathrm{Dd}=2.590$, $\mathrm{RMSEA}=0.0378, \mathrm{SRMR}=0.0305, \mathrm{GFI}=0.903, \mathrm{AGFI}=0.889, \mathrm{CFI}=0.932, \mathrm{NFI}=0.90$ ) obtained as a result of the confirmatory factor analysis conducted using the AMOS program showed that the scale had a valid structure. According to these results, the scale has become applicable to teachers and teacher candidates (Semerci, 2016).

The scale composes of 49 items five sub-dimensions as open-mindedness, systematicity, flexibility, perseverance and patience, and metacognition. The grading of the items was arranged as "strongly disagree", "mostly disagree", "slightly disagree", "mostly agree" and "strongly agree". Sub-dimensions and item numbers in the scale are given in Table 2:

\section{Table 2}

Sub-Dimensions of Critical Thinking Disposition Scale

\begin{tabular}{lccccc}
\hline \multirow{2}{*}{ Items } & Metacognition & Flexibility & Systematicity & $\begin{array}{c}\text { Perseverance } \\
\text { and patience }\end{array}$ & $\begin{array}{c}\text { Open- } \\
\text { mindedness }\end{array}$ \\
\cline { 2 - 6 } & $\mathbf{( 1 - 1 4 )}$ & $\mathbf{( 1 5 - 2 5 )}$ & $\mathbf{( 2 5 - 3 8 )}$ & $\mathbf{( 3 9 - 4 6 )}$ & $\mathbf{( 4 7 - 4 9 )}$ \\
\hline $\begin{array}{l}\text { The scale } \\
\text { itself } \alpha=\end{array}$ & .899 & .892 & .903 & .836 & .672 \\
$\begin{array}{l}\text { In this study } \\
\alpha=\end{array}$ & .410 & .818 & .835 & .805 & .668 \\
\hline
\end{tabular}

In the current study, the Cronbach Alpha coefficient of the CTD Scale was found to be 940 . In addition, Cronbach alpha reliability coefficients related to the sub-dimensions of the CTD scale were respectively $\alpha=.410 ; .818 ; .835 ; 805 ; .668$. as seen in Table 3 .

\section{Data Analysis}

Firstly, whether the scores obtained from the scales have normal distribution characteristics were examined and the equivalence of their variance was tested. These tests showed that total scores and scores of each variable type have a normal distribution. After the variances were understood to be homogeneous, parametrical tests such as t-test, ANOVA, Pearson correlation, two-way ANOVA, and regression were administered. The significance level of all operations was taken as $p<.05$. 


\section{Findings}

The normality test results regarding the data obtained from LS and CTD scales are shown in Table 3

\section{Table 3}

Normality Test Results

\begin{tabular}{lcccccc}
\hline \multirow{2}{*}{ Scales } & \multicolumn{3}{c}{ Kolmogorov-Smirnov $^{\text {a }}$} & \multicolumn{3}{c}{ Shapiro-Wilk } \\
\cline { 2 - 7 } & Statistic & df & Sig. & Statistic & df & Sig. \\
\hline \multirow{2}{*}{ LSS } &, 046 & 358 &, 061 &, 996 & 358 &, 434 \\
CTD &, 038 & 358 &, $200^{*}$ &, 992 & 358 &, 057 \\
\hline
\end{tabular}

The scores obtained from both scales were not significant according to Kolmogorov-Smirnov results since $n>50$. In other words, it was determined that the scores obtained from both scales showed normal distribution.

\section{Sub-Research Question 1}

The findings regarding the sub-research question 1 are given in Table 4 .

\section{Table 4}

The Relationship between Total LS and CTD Scores

\begin{tabular}{lcc}
\hline \multirow{2}{*}{ Total Scores of LS } & $\begin{array}{c}\text { CTD } \\
\text { Total Score }\end{array}$ & $\mathbf{p}$ \\
\cline { 2 - 3 } & $.500^{* *}$ & .000 \\
\hline
\end{tabular}

As shown in Table 5, there was a moderate level significant relationship between the total scores of LS and CTD. This finding means that both variables move together significantly in the moderate and positive direction. In this case, both variables change together at a certain level.

\section{Sub-Research Question 2}

The data obtained as a response to the second sub-question are presented in Tables 5, 6, 7, and 8, respectively. 


\section{Table 5}

The Relationship Between Age Levels and Total Scores of LS and CTD

\begin{tabular}{lcc}
\hline Age range & LS- CTD & p \\
\hline $17-18$ & $.500^{* *}$ & .000 \\
$19-20$ & $.476^{* *}$ & .000 \\
$21-22$ & $.732^{* *}$ & .000 \\
23 and over & $.505^{*}$ & .023 \\
\hline
\end{tabular}

The relationship between total scores of LS and CTD was at the level of .50 in 17-18 age range; .47 in 19-20 age range, .73 in 21-22 age range, and .50 at the age of 23 and over. Accordingly, while there was a moderately significant relationship between the total scores of LS and CTD in the age groups of 19-20 and 23 , this relationship was found to be higher and more significant in the age group of 21-22.

\section{Table 6}

The Relationship Between Total Scores of LS and CTD Total Scores Regarding Gender

\begin{tabular}{lcc}
\hline Gender & LS- CTD & p \\
\hline Female & $.499^{* *}$ & .000 \\
Male & $.506^{* *}$ & .000 \\
\hline
\end{tabular}

It was found that there was a moderate, positive, and significant relationship between females and LS-CTD scores $(r=.499)$. When considered from the perspective of males $(r=.506)$, similar findings were obtained. These findings show that there was a moderate level positive and significant relationship between gender variable and LS-CTD total scores.

\section{Table 7}

The Relationship Between Total Scores of LS and CTD Regarding the Graduated High School Type

\begin{tabular}{lcc}
\hline High School Type & LS- CTD & p \\
\hline Science High School -Anatolian High School and Anatolian Teacher & $.472^{* *}$ & .000 \\
Training High School & $.587^{* *}$ & .000 \\
General High School & $.489^{* *}$ & .000 \\
Fine Arts High School. -Imam Hatip High School -Vocational High & \\
School & & \\
\hline
\end{tabular}


As is seen in Table 7, there was a moderate level significant relationship between the total scores of LS and those of CTD in terms of the graduated high school type.

\section{Table 8}

The Relationship Between Total Scores of LS and Total Scores of CTD Regarding the Departments

\begin{tabular}{lcc}
\hline Department & LS- CTD & p \\
\hline English Language Teaching & $.583^{* *}$ & .000 \\
Maths Teaching & $.589^{* *}$ & .000 \\
Preschool Teaching & .150 & .389 \\
Psychological Counseling and Guidance & $.607^{* *}$ & .000 \\
Classroom Teaching & $.581^{* *}$ & .000 \\
Social Science Teaching & $.356^{* *}$ & .000 \\
Turkish & $.478^{* *}$ & .000 \\
\hline
\end{tabular}

Table 8 shows that a moderate level and significant relationship was found between English Language Teaching, Mathematics Teaching, Psychological Counseling and Guidance, Classroom Teaching and Turkish Language Teaching Departments, and total scores of LS and CTD. On the other hand, while this relationship level was not found to be very low and meaningful for Preschool Education Department, this relationship level was found to be low and statistically significant for Social Sciences Education.

\section{Sub-Research Question 3}

A two-way ANOVA test was administered to find an answer to the subresearch question 3. The obtained findings are presented in Table 9, 10, 11, and 12, respectively. 


\section{Table 9}

Comparison of The Total Scores of Age and LS and CTD Scores

\begin{tabular}{lcccccc}
\hline Source of Variance & Sum of Squares & df & Mean Squares & F & $\mathbf{p}$ & Effect Size \\
\hline Group & 2027.102 & 1 & 2027.102 & 15524.80 & .000 & .987 \\
Age & .608 & 3 & .203 & 1.552 & & \\
LS & 28.243 & 76 & .372 & 2.846 & .000 & .523 \\
Age* LS & 12.296 & 81 & .152 & 1.163 & & \\
Error & 25.723 & 197 & .131 & & & \\
Total & 5598.567 & 358 & & & & \\
\hline
\end{tabular}

As seen, the difference is significant when group and LS are considered separately. While the effect size was at the upper level for the group, it was determined that it was moderate in terms of LS. On the other hand, the results of joint effect with age level and age*LS were not significant. It was obtained that the CTD scores of the students did not differ significantly in terms of age variable. Similarly, it was seen that the common effect of the age*LS on the CTD scores was not significant.

\section{Table 10}

Comparison of the Differences Between Combination of Gender and LS and CTD Scores

\begin{tabular}{lcccccc}
\hline Source of Variance & Sum of Squares & $\mathbf{d f}$ & Mean Squares & $\mathbf{F}$ & $\mathbf{p}$ & Effect Size \\
\hline Group & 2815.934 & 1 & 2815.934 & 20781.95 & .000 & .989 \\
LS & .001 & 1 & .001 & .005 & & \\
Gender & 27.377 & 76 & .360 & 2.659 & .000 & .461 \\
Gender*LS & 6.505 & 44 & .148 & 1.091 & & \\
Error & 31.978 & 236 & .135 & & & \\
Total & 5598.567 & 358 & & & & \\
\hline
\end{tabular}

According to the results in Table 10, it is observed that the difference is significant when group and gender are considered separately. While the effect size is high for the group, it is at a medium level in terms of LS. On the other hand, the results were not found to be significant in terms of the LS alone and combined effect of LS*gender. 
In addition, the findings showed that the CTD scores of the students did not differ significantly in terms of gender variable. Similarly, it was seen that the common effect of the gender*LS on the CTD scores was not significant.

\section{Table 11}

Comparison of the Differences Between the Combination of Graduated High School Type and LS and CTD Scores

\begin{tabular}{lcccccc}
\hline Source of Variance & Sum of Squares & df & Mean Squares & F & p & Effect Size \\
\hline Group & 2184.100 & 1 & 2184.100 & 15856.93 & .000 & .986 \\
LS & 21.059 & 76 & .277 & 2.012 & .000 & .402 \\
High School Type & .684 & 2 & .342 & 2.483 & & \\
High School Type * LS & 6.956 & 52 & .134 & .971 & & \\
Error & 31.266 & 227 & .138 & & & \\
Total & 5598.67 & 358 & & & & \\
\hline
\end{tabular}

When Table 11 is examined, it is seen that group, department, LS variables were not significant in terms of CTD scores. Similarly, it was found that the common effect of department*LS on CTD score was not significant. The effect size levels were found to be small in terms of department variables. In addition, the common effect of LS and department*LS was found to be above the moderate level. Based on these findings, it is concluded that group, department, LS variables were significant in terms of CTD scores of the students. Similarly, the common effect of department*LS on CTD scores was found to be significant.

\section{Table 12}

Comparison of the Differences Between the Combination of Department and LS and CTD Scores

\begin{tabular}{lcccccc}
\hline Source of Variance & Sum of Squares & df & Mean Squares & F & p & Effect Size \\
\hline Group & 3281.147 & 1 & 3281.147 & 34884.704 & .000 & .996 \\
Department & 3.550 & 6 & .592 & 6.290 & .000 & .235 \\
LS & 24.246 & 76 & .319 & 3.392 & .000 & .677 \\
Dept*LS & 23.980 & 152 & .158 & 1.677 & .002 & .675 \\
Error & 11.569 & 123 & .094 & & & \\
Total & 5598.567 & 358 & & & & \\
\hline
\end{tabular}


Table 12 shows that the differences when group, department, LS, and department*LS are taken separately. While the effect size degree was also low in terms of the department, it was observed to be above the mid-level in terms of the combined effect of the group, the LS and department*LS. On the other hand, it was seen that the CTD scores of the students did not differ significantly in terms of the graduated high school type variable. Similarly, the common effect of high school type*LS on CTD scores was not significant

\section{Sub-Research Question 4}

Simple linear regression analysis was performed to determine whether the variables of age, gender, department, and high school type -taken separatelytogether with LS predicted CTD. The results obtained are given in Table 13, 14, 15, and 16 , respectively.

\section{Table 13}

Predictor Role of Age and LS On CTD

\begin{tabular}{lccccc}
\hline Model & $\mathbf{R}$ & $\mathbf{R}^{2}$ & $\begin{array}{c}\text { Corrected } \\
\mathbf{R}^{2}\end{array}$ & $\begin{array}{c}\text { Prediction } \\
\text { Se }\end{array}$ & Durbin-Watson \\
\hline 1 & .505 & .255 & .251 & .37738 & 1.986 \\
\hline
\end{tabular}

Simple regression analysis was applied to determine to what extent age and LS predicted CTD scores of the students. The findings show that $\mathrm{R}=.505, \mathrm{R}^{2}=.255$. Therefore, it was concluded that age and LS variables explain $25 \%$ of the total variance in CTD scores. Also, since the Durbin-Watson statistic value is close to 2 , it can be said that there is no autocorrelation between age and LS and CTD.

\section{Table 14}

ANOVA Table Regarding the Predictor Role of Age and LS on CTD

\begin{tabular}{lccccc}
\hline Model & Sum of Squares & df & Mean Squares & F & Sig. \\
\hline Regression & 17.300 & 2 & 8.650 & 60.735 & .000 \\
Residual & 50.559 & 355 & .142 & & \\
Total & 67.859 & 357 & & & \\
\hline
\end{tabular}

Table 14 shows the $\mathrm{F}$ test results showing the significance of the entire model. It is seen that age and LS of the regression model trying to explain the total variance of CTD $\left.\left[\mathrm{F}_{(2-355)}=60,675, \mathrm{p}<.05\right)\right]$ was found to be significant. 


\section{Table 15}

Parameters Regarding Age and LS'Prediction of CTD

\begin{tabular}{llccccc}
\hline \multirow{2}{*}{ Model } & \multicolumn{2}{c}{ Non-standard Coefficient } & \multicolumn{2}{c}{ Standard Coefficient } & \multirow{2}{*}{ t } & \multirow{2}{*}{ Sig. } \\
\cline { 2 - 5 } & B & Se & Beta & & \\
\hline \multirow{2}{*}{1} & (Constant) & 1.295 & .241 & & 5.373 & .000 \\
& Age & .037 & .025 & .067 & 1.461 & .145 \\
& LS & .727 & .066 & .502 & 10.958 & .000 \\
\hline
\end{tabular}

The coefficient of the regression model used for predicting age and LS and CTD was determined as 1.29 . When the $\beta$ values in the table are examined, it was seen that the predictor role of the age variable on CTD was not significant. On the contrary, the predictor role of the LS variable on CTS was significant $(\beta=.502$, $\mathrm{p}<.05)$.

\section{Table 16}

Regression Analysis Results Regarding Predictor Role of Gender and LS On CTD

\begin{tabular}{lccccc}
\hline Model & $\mathbf{R}$ & $\mathbf{R}^{2}$ & $\begin{array}{c}\text { Corrected } \\
\mathbf{R}^{2}\end{array}$ & $\begin{array}{c}\text { Prediction } \\
\text { Se }\end{array}$ & $\begin{array}{c}\text { Durbin- } \\
\text { Watson }\end{array}$ \\
\hline 1 & .501 & .251 & .247 & .37830 & 1.981 \\
\hline
\end{tabular}

The findings of the simple linear analysis showed that $\mathrm{R}=.505, \mathrm{R}^{2}=.255$. Therefore, it was concluded that gender and LS variables explain $24 \%$ of the total variance in CTD scores. Besides, since the Durbin-Watson statistic value is close to 2 , it can be said that there is no autocorrelation between gender and LS and CTD.

\section{Table 17}

ANOVA Table Regarding the Predictor Role Of Gender and LS on CTD

\begin{tabular}{lccccc}
\hline Model & Sum of Squares & df & Mean Squares & F & Sig. \\
\hline Regression & 17.053 & 2 & 8.527 & 59.581 & .000 \\
Residual & 50.805 & 355 & .143 & & \\
Total & 67.859 & 357 & & & \\
\hline
\end{tabular}

Table 17 shows the $\mathrm{F}$ test results showing the significance of the entire model. It is seen that the regression model in which gender and LS try to explain the total variance of CTD was found to be significant $[\mathrm{F}(2-355)=59,581, \mathrm{p}<.05)]$. 


\section{Table 18}

Parameters Regarding the Predictor Role of Gender and LS on CTD

\begin{tabular}{llccccc}
\hline \multirow{2}{*}{ Model } & \multicolumn{2}{c}{ Non-standard Coefficient } & \multicolumn{2}{c}{ Standard Coefficient } & \multirow{2}{*}{ t } & \multirow{2}{*}{ Sig. } \\
\cline { 2 - 5 } & B & Se & Beta & & \\
\hline 1 & (Constant) & 1.295 & .241 & & 5.373 & .000 \\
& Age & .037 & .025 & .067 & 1.461 & .145 \\
& LS & .727 & .066 & .502 & 10.958 & .000 \\
\hline
\end{tabular}

The coefficient of regression model used for the predictor role of gender and LS on CTD was found to be 1.40 , which is statistically significant. According to the $\beta$ values, it was seen that the predictor role of the gender variable on CTD was not significant. On the contrary, the predictor role of the LS variable on CTS was significant $(\beta=.502, \mathrm{p}<.05)$.

\section{Table 19}

Regression Analysis Results Regarding the Predictor Role of Graduated High School Type and LS On CTD

\begin{tabular}{lccccc}
\hline Model & $\mathbf{R}$ & $\mathbf{R}^{2}$ & $\begin{array}{c}\text { Corrected } \\
\mathbf{R}^{2}\end{array}$ & $\begin{array}{c}\text { Prediction } \\
\text { Se }\end{array}$ & $\begin{array}{c}\text { Durbin- } \\
\text { Watson }\end{array}$ \\
\hline 1 & .507 & .257 & .253 & .37694 & 1.985 \\
\hline
\end{tabular}

The findings in Table 19 show that $\mathrm{R}=.505, \mathrm{R}^{2}=.257$. Therefore, it was concluded that the graduated high school type and LS variables explain the $25 \%$ of the total variance in CTD scores. Also, since the Durbin-Watson statistic value is close to 2 , there is no autocorrelation between high school type and LS and CTD.

Table 20

ANOVA Table Regarding the Predictor Role of Graduated High School Type and LS on CTD

\begin{tabular}{lccccc}
\hline Model & Sum of Squares & df & Mean Squares & F & Sig. \\
\hline Regression & 17.420 & 2 & 8.710 & 61.302 & .000 \\
Residual & 50.439 & 355 & .142 & & \\
Total & 67.859 & 357 & & & \\
\hline
\end{tabular}

F test results presented in Table 20 showed that the regression model in which high school type and LS tries to explain the total variance of CTD was found to be significant $\left.\left[\mathrm{F}_{(2-355)}=61,309 ; \mathrm{p}<.05\right)\right]$. 


\section{Table 21}

Parameters Regarding the Predictor Role of High School Type and LS on CTD

\begin{tabular}{llccccc}
\hline \multirow{2}{*}{ Model } & \multicolumn{2}{c}{ Non-standard Coefficient } & Standard Coefficient & \multirow{2}{*}{ t } & \multirow{2}{*}{ Sig. } \\
\cline { 2 - 5 } \cline { 3 - 5 } & B & Se & Beta & & \\
\hline 1 & (Constant) & 1.357 & .235 & & 5.779 & .000 \\
& high school type & .046 & .026 & .080 & 1.728 & .085 \\
& LS & .710 & .067 & .491 & 10.642 & .000 \\
\hline
\end{tabular}

The coefficient of the regression model was found 1.35 , which is statistically significant. When the $\beta$ values are examined, when the independent variables were added to the regression model, the predictor role of the high school variable on CTD was found to be insignificant $(\beta=.080 ; \mathrm{p}>.05)$. On the contrary, the predictor role of LS on CTD was found to be significant $(\beta=.491, \mathrm{p}<.05)$.

\section{Table 22}

Regression Analysis Results Regarding the Predictor Role of Department and LS on CTD

\begin{tabular}{lccccc}
\hline Model & $\mathbf{R}$ & $\mathbf{R}^{2}$ & $\begin{array}{c}\text { Corrected } \\
\mathbf{R}^{2}\end{array}$ & $\begin{array}{c}\text { Prediction } \\
\text { Se }\end{array}$ & $\begin{array}{c}\text { Durbin- } \\
\text { Watson }\end{array}$ \\
\hline 1 & .503 & .253 & .248 & .37798 & 1.974 \\
\hline
\end{tabular}

The findings show that $\mathrm{R}=.505, \mathrm{R}^{2}=.253$. Therefore, it was concluded that department and LS variables explain $25 \%$ of the total variance in CTD scores. In addition, since the Durbin-Watson statistic value obtained when department and LS variables were added to the regression model, is close to 2 , there is no autocorrelation between department and LS and CTD.

\section{Table 23}

ANOVA Table Regarding the Predictor Role of Department and LS on CTD

\begin{tabular}{lccccc}
\hline Model & Sum of Squares & df & Mean Squares & F & Sig. \\
\hline Regression & 17.140 & 2 & 8.570 & 59.987 & .000 \\
Residual & 50.718 & 355 & .143 & & \\
Total & 67.859 & 357 & & & \\
\hline
\end{tabular}

The $\mathrm{F}$ test results show that the regression model was found significant $[\mathrm{F}$ $(2-355)=59,987 ; \mathrm{p}<.05)]$. 


\section{Table 24}

Parameters Regarding the Predictor Role of Department and LS on CTD

\begin{tabular}{llccccc}
\hline \multirow{2}{*}{ Model } & \multicolumn{2}{c}{ Non-standard Coefficient } & Standard Coefficient & \multirow{2}{*}{ t } & \multirow{2}{*}{ Sig. } \\
\cline { 2 - 5 } & B & Se & Beta & & 5.724 & .000 \\
\hline 1 & (Constant) & 1.352 & .236 & & 1.007 & .315 \\
& Department & .009 & .009 & .046 & 10.74 & .000 \\
\hline
\end{tabular}

The coefficient of the regression model was found to be 1.35 , which is statistically significant. According to the $\beta$ values, when the independent variables were added to the regression model, the predictor role of the department variable on CTD was found to be insignificant. On the contrary, the predictor role of LS on CTD was found to be significant.

\section{Discussion}

The results of this study revealed that there was a moderate level significant relationship between the total scores of LS and the CTD. It can be concluded that the correlation between pre-service teachers' LS and CTD should not be ignored. It is seen that similar findings were obtained in some studies (Çağrı, 2014; Colucciello, 1999; Nosratinia \& Soleimannejad, 2016; Siriopolus et al. 2007).

On the contrary, in some studies (Beşoluk \& Önder, 2010; Conceição, 2004; Kiriş-Avaroğulları \& Şaman, 2020; Kösece et al., 2015; Mahmoud, 2012; Mcdade, 2000; Mohomad et al., 2017; Myers \& Dyer, 2006) there was not a significant relationship between LS and CTD. The differences in the findings may result from the different scales used in the studies, the characteristics of the participants, and the different variables that were examined.

It was found that there was a moderate level relationship between LS and CTD total scores and 17-18, 19-20, and 23 and above age groups. Also, there was a higher level and significant relationship between LS and CTD total scores and the 21-22 age group. In this context, it can be said that the age variable is one of the factors which can affect the LS and CTD of the students. This finding contradicts the findings of the study conducted by Mcdade (2016). Moreover, the studies revealing the relationship between the age variable and the LS and CTD are limited. 
The findings also showed that there was a moderate level, positive and significant relationship between gender, graduated high school type, department variables, and LS and CTD total scores. In some studies, (Karademir \& Tezel, 2010; Heffler, 2001; Perry \& Ball, 2004) moderate level, positive and significant relationship was obtained between gender variable and LS and CTD total scores. However, the findings of the study contradicts with some studies in the literature (Çağrı, 2004; Çetin, 2014; Dikmen et al. 2018; Gürsoy Dikmen \& Saracaloğlu, 2011; Jones et al. 2003; Kılıç \&Karadeniz, 2004; Kiriş-Avaroğulları \& Şaman, 2020; Mcdade 2016; Myers and Dyer; 2006; Tezci \&Ataseven, 2016; Ünal et al. 2013).

On the other hand, the significant relationship obtained in this study between LS and CTD show similarity with the findings of some studies (Çetin, 2014; Çağr1, 2004; Perry \& Ball, 2004; Jones et al. 2003). However, they contradict with some studies (Bahar \&Sülün, 2011; Küçükkaragöz et al. 2008; Metallidou \& Platsidou, 2007), which indicated that LS did not differ in terms of department variable. On the other hand, in this study, the relationship between the graduated high school type variable and LS and CTD scores could not be proved. However, in terms of LS, Karamustafaoğlu et al. (2017) concluded that the high school type that the teacher candidates graduated from did not affect their LS. LS is unique for each individual. Therefore, it is an expected result that LS and CTD differ significantly in terms of gender, cognitive domain, skills, and the department variable.

The findings of the study contract with some studies in the literature which may be due to the characteristics taken as a basis in the LS models and classifications. In other words, it can be thought that classifications on LS highlight certain dimensions (cognitive, affective and physiological, social interaction, etc.) as a priority. Therefore, the factor structures and question contents of the data collection tools used to determine the LS characteristics will also be different. It is seen that the CTD scale is mainly used for data collection in the studies in the literature; therefore, it is thought that the differences that may arise from the sociocultural context are ignored in the related studies while collecting data on CTD and skills. The findings in this study may be due to the appropriateness of the scale developed by Semerci (2006) to the socio-cultural characteristics conditions in Turkey. In summary, in this study, among the possible reasons for the inconsistency of the results of the studies in the literature and this study, assumptions are based on 
the research, the data collection tools with different structures and characteristics, and socio-cultural differences.

The common effect of age, gender, and graduated high school type were not significant with LS. On the contrary, the common effect of department and LS was significant at a moderate level. These findings show similarity with the findings of the study conducted by Tezci and Ataseven (2016), in which the common effect of gender, department, and learning style was not significant. The most striking result in these findings is that the common effect of high school type and department variables, which are considered to be related to individual differences such as intelligence and skill LS was not significant. This may result in the factors such as differences in activities conducted during the teaching-learning process and differences in their qualities, teacher behaviors, factors belonging to the school and its environment, etc.

When age and LS; gender and LS, department and LS, and graduated high school type and LS were considered together, each independent variable group could predict approximately $25 \%$ of the CTD. However, when age, gender, high school type, department variables were added to the regression analysis with LS, it was seen that they were not included in this $25 \%$ explanation rate on their own. Therefore, this predictive ratio alone gives meaningful results in terms of LS. This situation brings to mind the need to investigate other individual and environmental factors other than these independent variable groups in the explanation of CTD.

\section{Conclusion and Recommendations}

According to these results, it can be said that there is a moderate level and significant relationship between LS and CTD, considering the variables of age, gender, department, and graduated high school type variables. Accordingly, while organizing teaching-learning processes, different LS specific to individuals and skills related to CTD should be considered together. For this, instead of relying on a single learning style or CTD model, approaches and tools that will define the individual and his/her socio-cultural environment as a whole should be put into practice first. Based on the findings of the study, it can be said that rich learning experiences that highlight diversity in terms of interaction, method, technique, material, etc. should be designed and implemented to improve teacher candidates' 
LS and critical thinking skills. Due to the favorable conditions provided to the individual, the effectiveness of their learning experiences can be increased, it can be enabled that teacher candidates gain awareness of their own LS and to become individuals who question, research and renew themselves.

\section{References}

Accelerated programmes. İnternational Nursing Review, 53(1),73-79.

Alkın-Şahin, S. \&Tunca, N. (2013). Düşünme becerileri, düşünmeyi destekleyen sınıf ortamı ve öğretmen davranışları. G. Ekici (ed.). Öğretme-Öğrenme Yaklaşımları ve Uygulama Örnekleri. İçinde (s.391-425). Pegem Akademi Yayıncılık

Andreou, C., Papastavrou, E. ve Merkouris, A. (2014). LS and critical thinking relationship in baccalaureate nursing education: A systematic review. Nurse Education Today, 34(3), 362-371. https://www.ncbi.nlm.nih.gov/pubmed/23830067

Arı, E. (2011). Temel kavramlar. S. Büyükalan Filiz (ed.). Öğrenme öğretme kuram ve yaklaşımları. İçinde (s.2-21). Pegem Akademi Yayıncılık.

Başar, H. (2013). Nasıl düşünelim? Pegem Akademi Yayıncılık

Beşoluk, Ş. ve Önder, İ. (2010). Investigation of teacher candidates' learning approaches, LS and critical thinking dispositions1. Elementary Education Online, 9(2), 679693

Biggs, J. (2001). Enhancing Learning: A Matter of Style or Approach. Ed.: Robert J. Sternberg ve Li- Fang Zhang. Perspectives on Thinking, Learning and Cognitive Styles. Lawrance Erlbaum Associates, Mahwah, ss.73-102.

Bilasa, P. (2011). Öğrenme stilleri ve stil odaklı öğretim tasarımı. S. Büyükalan Filiz (ed.).

Öğrenme öğretme kuram ve yaklaşımları. İçinde (s.206-230). Pegem Akademi Yayıncilik.

Bulurman, B. (2002). Enformasyon toplumu ve eğitim. http://www.isguc.org/?p=article\&id $=124 \&$ cilt $=4 \&$ sayi $=1 \&$ yil $=2002$

Claxton C. S. \& Ralston I. (1978). LS: Their impact on teaching and administration. National Institute of Education.

Cohen, A. D. (2001). Preparing teachers for styles and strategies based instruction, Proc. of International Conference on Language Teacher Education, 17-19.

Colucciello, M.L. (1999). Relationships between critical thinking dispositions and LS. Journal of Professional Nursing, 15(5)294-301.https://doi.org/10.1016/S87557223(99)80055-6

Conceição, S. (2004) Learning style and critıcal thinkıng in an onlıne course that uses concept maps: Theory, Methodology, Technology Proc. of the First Int. Conference 
on Concept Mapping Pamplona, Spain http://cmc.ihmc.us/papers/cmc2004-061. pdf

Creswell, J.W. (2013) Educational Research: Planning, conducting, and evaluating quantitative and qualitative research. (4. Ed.) Pearson Education

Çetin, M. Ç. (2014). Evaluation of the correlation between LS and critical thinking dispositions of the students of school of physical education and sports. Educational Research and Reviews, 9(18), 680-690.

Dikmen, M., Bahadır, F. \& Akmençe, A., E. (2018). Öğretmen adaylarının öğrenme stillerinin bazı değişkenler açısından incelenmesi. Journal of Educational Reflections, 2(1), 24-37.

Dilekli, Y. (2017). The relationships between critical thinking skills and LS of gifted students. European Journal of Education Studies, 3(4), 69-96 https://oapub.org/ edu/index.php/ejes/article/view/552

Doğan, İ. (2004). Toplum ve eğitim. Pegem Akademi Yayıncıllk

Domino, G. (1970). Interactive effects of achievement orientation and teaching style on academic achievement. ACT Research Report, 39, 1-9.

Drucker, P.F. (1993). Kapitalist ötesi toplum. (B. Çorakçı, Çev.). İnkılap Yayınları.

Dunn K. \& R. Dunn (1986). The look of LS. Early Years, 8, 46 - 52.

Entwistle, N. J. (1981). Styles of learning and teaching. Wiley.

Epstein, R. L. ve Kernberger, C. (2006). Critical thinking (Third Edition). Thomson Wadsworth.

Felder, R. M. \& Silverman L. (1988). Learning and teaching styles in engineering education. Engineering Education, 78(7), 674-681.

Felder, R. M. (1996). Matters of style. ASEE Prism, 6(4), 18-23.

Fisher, A. (2001). Critical Thinking an introduction. Cambridge University Press.

Gencel, İ. E. (2016). Öğrenme stilleri ve stil odaklı öğretim. G. Ekinci (ed.). Öğrenmeöğretme kuramları ve uygulamadaki yansımaları. İçinde (s.612-637). Pegem Akademi Yayıncilık.

Ghazivakili, Z., Norouzi Nia, R., Panahi, F., Karimi, M., Gholsorkhi, H., \& Ahmadi, Z. (2014). The role of critical thinking skills and LS of university students in their academic performance. Journal of Advances in Medical Education \& Professionalism, 2(3),95-102. https://www.ncbi.nlm.nih.gov/pmc/articles/ PMC4235550/

Grasha, A. F. (1996). Teaching with style: A practical guide to enhancing learning by understanding teaching and LS. Allianca Publishers

Gürbüz. S. ve Şahin, F. (2017). Sosyal bilimlerde araştırma yöntemleri. (4. Bask1). Seçkin 
Yayınları

Gürsoy Dikmen, T. \& Saracaloğlu, A. S. (2011). Analysis of LS of preservice teachers in terms of various variables. Adnan Menderes University Faculty of Education Journal of Educational Sciences, 2(1), 52-74

Güven. M. ve Kürüm, D. (200, 06.09.2004). Öğrenme stilleri ve eleştirel düşünme arasındaki ilişkiye genel bir bakış. XIII. Ulusal Eğitim Bilimleri Kurultayında sunulan bildiri, 6-9 Temmuz 2004 İnönü Üniversitesi, Ĕ̆itim Fakültesi, Malatya. https://www.pegem.net/dosyalar/dokuman/408.pdf

Heffler, B. (2001). Individual learning style and the learning inventory. Educational Studies. 27(3), 307-316.

Helvacı, Mehmet, Akif (1998). "Bilgi Toplumunun Gerektirdiği İnsan Gücü Nitelikleri Açısından Toplumdaki Bireylerin Niteliklerinin Değerlendirilmesi.”Yayınlanmamış yüksek lisans tezi. Afyon Kocatepe Üniversitesi sosyal Bilimler Enstitüsü, Afyon. https://doi.org/10.1111/j.1466-7657.2006.00445.x

Jones, C., Reichard, C \& Mokhtari, K. (2003). Are students' LS discipline specific? Community College Journal of Research and Practice. 27, 363-375.

Karademir, E. ve Tezel, Ö. (2010). Sınıf öğretmeni adaylarının öğrenme stillerinin demografik değişkenler açısından incelenmesi. Pamukkale University Journal of Education, 28(2), 129-145.

Karasar, N. (2003). Bilimsel araştırma yöntemi. (12.Baskı). Nobel Yayın Dağıtım.

Kilıç, E. \& Karadeniz, Ş. (2004). The effects of gender and learning style on navigation strategy and achievement. Gazi University Journal of Education Faculty, 24 (3), 129-146.

Kiriş-Avaroğulları, A. \& Şaman, B. (2020). Investıgation of the relationship between LS and critical thinking tendencies of social studies teacher candidates. Mehmet Akif Ersoy University Journal, 53, 411-434.

Kolb, D. A., (1984). Experiential learning. Prentice-Hall Inc.

Kösece, P., Üredi, L. \& Akbaşl1, S. (2015). The relationships between preser vice class teachers' LS and personality characteristics. Turkish Studies, 10(7) 675-688

Kürüm, D. (2008). Öğrenme stilleri. K. Selvi (Ed.). Öğretim İlke ve Yöntemleri. Anadolu University Open Education Faculty Publications.

Lukow, J. E. (2002). LS as predictors of student attitudes toward the use of technology in recreation courses. Unpublished doctoral thesis. Indiana University.

Mahmoud H.G. (2012). Critical thinking dispositions and 1s of baccalaureate nursing students and its relation to their achievement. International Journal of Learning and Development 2(1),398-415. http://www.macrothink.org/journal/index.php/ 
ijld/article/view/1379

Mcdade, D. C. (2000). Relationships between LS and critical thinking ability among health professional students. Dissertation Abstracts International Section A: Humanities and Social Sciences, 61(6-A), 2212.

Mertens, D.M. (1998). Research methods in education and psychology. Sage Publication Inc.

Metallidou, P. \& Platsidou, M. (2008). Kolb's learning style inventory-1985: validity issues and realtions with metacognitive knowledge about problem-solving strategies. https://doi.org/10.1016/j.lindif.2007.11.001

Meyers, C. (1986). Teaching students to think critically. Jossey-Bass PublishersMichigan: The center for research on learning and teaching. The University of Michigan.

Mohamad, M. M., Jamali, A. R., Mukhtar, M. I., Sern L. C. \& Ahmad, A. (2017).”LS and critical thinking skills of engineering students," 2017 IEEE 9th International Conference on Engineering Education (ICEED), 54-58.

Mumford, A. (1987). LS and learning. Personnel Review, 16(3), 20-23.

Myers, B.E \& Dyer, J. (2006). The influence of student LS on critical thinking Journal of Agricultural Education 47(1), 43-52.

Norris, S. P. (1985). Synthesis of research on critical thinking. Educational Leadership, 42(8), 40-45.

Nosich, G. M. (2012). Eleştirel düşünme ve disiplinlerarası eleştirel düşünme rehberi. (Çev. B. Aybek). Anı Yayıncılık.

Özdemir, S. M. (2005). Üniversite öğrencilerinin eleştirel düşünme becerilerinin çeşitli değişkenler açısından değerlendirilmesi. Türk Eğitim Bilimleri Dergisi, 3(3), 297316.

Özden, Y. (2003). Öğrenme ve öğretme. (7 bask1). Pegem Akademi Yayınc1lı

Özer, B. (2002). İlköğretim ve ortaöğretim okullarının eğitim programlarında öğrenme stratejileri. Ĕgitim Bilimleri ve Uygulama Dergisi,1(1),17-32.

Patureau, V. (1990). Styles d'apprentissage et ordinateur. In Dans R. Duda \& Duda P. Riley (Ed.) LS. Nancy Presses.

Paul, R. \& Elder, L. (2013). Kritik düşünce (Çev. Esra Aslan ve Gamze Sart).Nobel Yayınlar1

Perkins, N.D. (1999). The many face of constructivisim. Educational Leadership, 57(3),611

Perry, C. \& Ball, I. (2004). Teacher subject specialisms and their relationships to LS, psychological typesand multiple intelligences: implications for course development. Teacher Devolopment, 8(1), 9-28. 
Schunk, D. H. (2009). Öğrenme teorileri eğitimsel bir bakışla, Çev. Ed. Muzaffer Şahin, PhD. 5. Baskıdan Çeviri. Nobel Yayın Dağıtım.

Senemoğlu, N. (2003). Gelişim ögrenme ve öğretim. (25. Bask1). Anı yayıncılık.

Siriopoulos, C. \& Pomonis, G. A. (2007). Learning Style Changes and Their Relationship to Critical Thinking Skills. Journal of College Teaching and Learning, 4(1), 45-60.

Snyder, R. F. (2000). The relationship between LS/multiple intelligences and academic achievement of high school students. The High School Journal, 83(2),11-20.

Sönmez, V. (2012). Program geliştirmede ögretmen elkitabı. (17 b.). Anı Yayınc1lık.

Suliman, W. A. (2006). Critical thinking and LS of students in conventional and

Tatar, E. \& Tatar, E. (2007). Öğrenme stillerine dayalı öğretim, Journal of Qafqaz University, 20(13-20), 126-130.

Tezci, E. \& Ataseven, N. (2016). Effects of learning style and demographic factors on learning strategies Journal of Educational Sciences Research, 6(1), 211-225.

Ünal, K., Dilbaz Alkan, G., Özdemir, F.B. \& Çakır, Ö. (2013). An analysis of the LS and strategies of the students in faculty of education in relation to various variables (Mersin University Sample). Mersin University Journal of Education Faculty,9(3),56-76.

Veznedaroğlu, R.L. \& Özgür, A.O (2005). Öğrenme stilleri: Tanımlamalar, modeller ve işlevleri. İlköğretim Online. 4(2), 1-16

Yazıcıŏlu, Y. ve Erdoğan, S. (2004). SPSS uygulamalı bilimsel araştırma yöntemleri. Detay Yayınc1lik.

Yurdakul, Bünyamin (2004) The effects of constructivist learning approach on learners' problem solving skills, metacognitive awareness, and attitudes towards the course, and contributions to learning process. (Unpublished doctoral thesis). Hacettepe Univesity Social Sciences Institute. 